\title{
Duns Scotus on Signification
}

\author{
DOMINIK PERLER
}

In both versions of his Commentary on the Sentences, Scotus alludes to a great controversy among his contemporaries over the question of whether a spoken word signifies a thing or a concept. He does not give a detailed account of this controversy, but confines himself to saying, "in short, I grant that what is properly signified by a spoken word is a thing." 1 This brief statement may seem trivial at first sight, but it turns out to be innovative when it is assessed against the background of medieval Aristotelian semantic theory. From Boethius onwards, the overwhelming majority of the commentators on $D e$ interpretatione held that it is a concept and not a thing that is primarily and directly signified by a spoken word.2

1. John Duns Scotus Ordinatio 1.27.1-3 in Opera Omnia, ed. Commissio Scotistica (Vatican City: Typis Polyglottis, 1950- ) 6:97. 'Licet magna altercatio fiat de 'voce,' utrum sit signum rei vel conceptus, tamen breviter concedo quod illud quod signatur per vocem proprie, est res." See also John Duns Scotus Lectura in librum primum Sententiarum 1.27.1-3 (Commissio Scotistica 17:357).

2. See Boethius Commentarii in librum Aristotelis Peri hermeneias 1.1, ed. C. Meiser (Leipzig: Teubner, 1880 and 1877), pp. 38-40; and Boethius Commentarii in librum Aristotelis 2.1 (Meiser pp. 25-29). An extensive commentary on these crucial passages is provided by John Magee, Boethius on Signification and Mind (Leiden: Brill, 1989), pp. 49-92. On the medieval reception, see Jean Isaac, Le Peri hermeneias en occident de Boèce à Saint Thomas: Histoire littéraire d'un traité d'Aristote (Paris: Vrin, 1953), pp. 3597. On the most important thirteenth-century commentators, see the thorough 
In this paper, I intend to examine the reasons that led Scotus to criticize and revise the dominant theory. Such an examination can scarcely be restricted to a logico-semantical analysis. ${ }^{3}$ An adequate understanding of the relationship between a sign and its significate not only necessitates an examination of the question of how this relationship is established, but also a discussion of the question of what exactly the sign and the significate are-what kind of entities they are. Therefore, the following analysis aims at investigating not only the semantic aspects of Scotus's theory of signification, but also its ontological commitments.

\section{CLASSIFICATION OF SIGNS}

Scotus discusses the semantic function of words within the framework of a general theory of signs. He states that signs can be classified by regarding either (a) their relation to the significate or (b) the significate itself. ${ }^{4}$ (a) If signs are classified as regards their relation to the significate, they can be divided into natural and conventional signs. Natural signs have a significative function by nature; they are linked to their significate by a real relation. Conventional

historical introduction in Thomas Aquinas Expositio libri Peryermenias, ed. R.-A. Gauthier (Rome/Paris: Commissio Leonina and Vrin, 1989), pp. 64*-84*. Roger Bacon also claims that a spoken word directly signifies a thing; see his Compendium studii theologiae 2.2, ed. T. S. Maloney (Leiden: Brill, 1988), p. 68. However, Bacon differs significantly from Scotus in his explanation of what the signified thing is (for which, see below). Because of this different ontological commitment, it would be misleading to introduce Scotus and Bacon as two allies fighting together against the traditional theory.

3. Daniel O. Dahlstrom, in "Signification and Logic: Scotus on Universals from a Logical Point of View," Vivarium 18 (1980): 83, chooses a logico-semantical approach, claiming that "Scotus greatly insures the autonomy of logic from metaphysics, psychology, and grammar." Marmo points out the inadequacies of this approach; see his "Ontology and Semantics in the Logic of Duns Scotus," in On the Medieval Theory of Signs, ed. Umberto Eco and C. Marmo (Amsterdam and Philadelphia: John Benjamins, 1989), pp. 143-144. Scotus elaborated a theory of signs, including their epistemological and ontological aspects, rather than an autonomous logic.

4. Scotus Reportatio 4.1.2 in Opera Omnia 23, ed. L. Wadding (rptd. Paris: Vivès, 1891-95), p. 546. 
signs receive their significative function ad placitum; they are linked to their significate only by a conceptual relation. ${ }^{5}$ Nevertheless, the relation beween conventional signs and their significate does exist. Scotus emphasizes that everything that does not include a contradiction exists, whether it has real or conceptual existence, ${ }^{6}$ and he claims that a relation (whether real or conceptual) is a peculiar being that cannot be reduced to any other category of being. ${ }^{7}$

Scotus's distinction between natural and conventional signs is traditional. It can be found in many medieval classifications of signs. Natural signs were usually subdivided into non-linguistic natural signs - the groaning of a sick person (natural sign of the sickness) or the barking of a dog (natural sign of its excitement) - and linguistic natural signs. ${ }^{8}$ Following Aristotle's De interpretatione $1.16 \mathrm{a} 3-8$ and Augustine's De Trinitate 15.10-11, many medieval commentators identified the linguistic natural signs with the "affections in the soul" (passiones animae) or the "words in the heart" (verba in corde) that are the same for all human beings, regardless of the language they speak. ${ }^{9}$

Scotus gives examples only for conventional signs, namely, the gestures of monks living under a vow of silence (non-linguistic conventional signs) and spoken words (linguistic conventional signs). These signs are called conventional, "because they can signify other things as well as these things, if it suited the people who impose [the signs]." 10 Thus, conventional signs are distinguished by two features: they can have significates other than those they happen to have, and their signification is arbitrarily fixed by the sign-users.

5. Scotus Reportatio 4.1.2 (Wadding 23:546).

6. Scotus Quodl. 3 (Wadding 25:114).

7. See Mark G. Henninger, Relations: Medieval Theories, 1250-1325 (Oxford: Clarendon Press, 1989), pp. 68-97 (with numerous references).

8. See, for instance, Roger Bacon De signis in "An Unedited Part of Roger Bacon's Opus Maius: De signis," ed. Karin Margareta Fredborg, Lauge Olaf Nielsen, and Jan Pinborg, Traditio 34 (1978): 82-84. On the sources of this division, see Alfonso Maierù, "Signum dans la culture médiévale," in Sprache und Erkenntnis im Mittelalter: Akten des VI. Internationalen Kongresses für mittelalterliche Philosophie, ed. Wolfgang Kluxen et al., Miscellanea Mediaevalia 13 (Berlin and New York: de Gruyter, 1981) 1:51-72.

9. On the distinction between natural and conventional signs, which was a topos of medieval philosophy from Boethius onwards, see J. Engels, "Origine, sens et survie du terme boécien 'secundum placitum'," Vivarium 1 (1963): 87-115.

10. Scotus Reportatio 4.1.2 (Wadding 23:546). 
The relation between a conventional sign and its significate is conceptual, for the sign exists qua sign (not qua material thing) only if it is linked to a concept. The spoken word 'human being', for instance, has a significative function only if it is associated with the concept human being; otherwise, it would simply be a noise. The monk's gestures can be labeled a sign only if the monk intends to make some other monk understand something; otherwise, the gestures would simply be a movement of the body.

To whose concept must a conventional sign be related in order to have a significative function: to the concept of the sign-user, of the sign-receiver, or of both? Scotus distinguishes between a perfect and an imperfect use of a conventional sign, taking the spoken noun as example. If such a noun is used perfectly, both the utterer and the hearer must associate it with a concept. The use is imperfect if the utterer never associates the spoken noun with a concept (as with a well-trained parrot repeating words it has heard) or if the utterer actually cannot associate the spoken noun with a concept (as with a Latin speaker who utters a Hebrew word without knowing Hebrew). ${ }^{11}$ Scotus does not mention the case in which only the utterer, but not the hearer, associates the spoken noun with a concept (as with a Latin speaker talking in Latin to a public that understands only Hebrew). Nor does he discuss the case in which utterer and hearer associate two different concepts with one and the same spoken noun (as with a German speaker who utters the word 'gift' and associates the concept poison with it, while an English hearer associates the concept present). Presumably, Scotus also classifies these cases as imperfect uses of conventional signs.

(b) If signs are classified as regards their significate, they can be divided as follows: some signs have their "significate with them" (signatum secum). They are necessarily accompanied by their significate, thus being "true and effective." Some natural signs, Scotus writes, belong to this class. An eclipse, for instance, is such a sign, since it is necessarily accompanied by the interposition of the earth

11. Scotus Reportatio 1A.22.unica (Commissio Scotistica 5:390). Although both the parrot and the Latin speaker uttering a Hebrew word lack a concept, Scotus clearly distinguishes the two cases. The Latin speaker is able to learn Hebrew and, consequently, to associate a concept with the Hebrew word; the parrot never has this ability. 
between sun and moon. ${ }^{12}$ Other signs lack the co-presence of the significate. When someone utters a proposition, the proposition is not necessarily accompanied by its significate, since a proposition can express something that is not the case, no longer the case, or not yet the case. That is why a proposition can be a "false sign" as well as a "true sign."13

It is clear from these general distinctions that Scotus classifies spoken words among the conventional signs that are not necessarily accompanied by their significate. This claim raises at least two important questions. (1) How is the relationship between a spoken word and its significate established, and what is the significate-the extramental thing itself or its mental representation? (2) How can the utterer of a spoken word judge whether he or she utters a true sign in the absence of the significate?

\section{RELATIONS OF SIGNIFICATION}

Scotus's answers to these questions can be found in his commentary on De interpretatione (extant in two versions), where he discusses the question of what a spoken word signifies. ${ }^{14} \mathrm{He}$ opens the discussion with the remark that "the question is not understood regarding nouns that are imposed to signify likenesses (similitudines) or species, but regarding every other noun, whatever it might be imposed on, such as 'human being,' 'animal,' etc."15 Although this remark seems to be made in passing, it should not be overlooked, since it

12. Scotus Reportatio (Wadding 23:546). Note that not all natural signs are accompanied by their significate. A hoofprint, for example, is a natural sign referring to a horse, but it is not necessarily accompanied by a horse.

13. Scotus Reportatio 4.1.2 (Wadding 23:546).

14. See Scotus In primum librum Perihermeneias quaestiones 2 (Wadding 1:540 44), hereafter cited as In Perih., and In duos libros Perihermeneias, operis secundi, quod appellant, quaestiones octo 1 (Wadding 1:582-85), hereafter cited as In Perih. II. There are still some difficulties concerning the authenticity of and the relationship between these two works, which I will not discuss here. (The final word remains to be said by the scholars at the Franciscan Institute in St. Bonaventure, who are preparing the critical edition.) My analysis will mostly be based on the first set of questions.

15. Scotus In Perih. 2 (Wadding 1:540). 
fixes the scope of the entire investigation. (i) Scotus excludes nouns exclusively signifying mental entities or mental acts (e.g., 'concept', 'thought'), because such nouns never have an extramental significate. (ii) By citing the examples 'human being' and 'animal', which are nouns of first imposition, Scotus seems to leave out of account the nouns of second imposition, i.e., the nouns that signify other nouns (e.g., 'substantive'). ${ }^{16}$ (iii) The examples suggest that Scotus confines the investigation to common nouns (or general terms), disregarding singular terms such as 'Socrates'. This restriction deserves special attention, since common nouns are exactly the nouns on which the controversial debate over universals focuses. The common noun 'animal', for instance, is the noun signifying the genus animal, so that the question "What is the significate of 'animal'?" is closely related to the question "What is the genus animal?"

Scotus gives two alternatives for explaining the significate of a spoken common noun: it is either a thing (res) or a species in the soul (species in anima). He defines the species as an "intelligible likeness of intelligible objects that is in the intellect as in a subject, just as a sensible species is a likeness of a sensible thing that is in a sense as in a subject." 17 The intelligible species is a mental entity-ontologically speaking, a quality of the intellect - which is produced by the intellect on the basis of a sensible species and which functions to represent the understood thing. The relationship between sensible and intelligible species may be explained as follows. When someone sees a table, he or she first receives a kind of visual image of the table in the sensitive part of the soul (the sensible species of the table), and then he or she is able to produce a cognitive image of the table in the intellective part of the soul (the intelligible species). Sensible and intelligible species are distinct, since they are in two distinct parts (or facultates) of the soul. ${ }^{18}$ In contrast to the sensible species, the intelligible species is

16. On this distinction, which has its origin in late ancient grammar, see Mario Dal Pra, "Sulla dottrina della impositio prima et secunda," Rivista critica di storia della filosofia 9 (1954): 390-399; and Christian Knudsen, "Intentions and Impositions," in CHLMP, pp. 479-495.

17. Scotus In Perih. 2 (Wadding 1:540).

18. This is, of course, a simplified account of the production and interrelation of the species. For a detailed introduction to the epistemological species-theory, which is closely related to optical theory, see A. Mark Smith, "Getting the Big 
not merely a passing imprint of the thing, but a cognitive image that can exist even when the represented thing is not present. ${ }^{19}$ Being a kind of mental counterpart to the thing, the intelligible species is also called a similitudo. ${ }^{20}$

Since the intelligible species is necessary for an act of intellective understanding, one might claim that it is also necessary for an act of signifying, assuming that a person uses the word 'table' significantly (and not just as a noise) if he or she signifies the mental likeness of a table. This assumption is at the core of the discussion, for it raises the question: In what sense is the intelligible species necessary for an act of signifying? Is it only a mediating mental entity between a conventional sign and its significate, or is it the significate itself?

Scotus answers this question by distinguishing two aspects of the intelligible species: its ontological status and its function. He claims that a species can be regarded either insofar as it is an accident affecting the soul, or insofar as it represents a thing. ${ }^{21}$ The species considered under the first aspect, i.e., under the ontological aspect of its existence as a mental accident, is not the significate of a spoken word. Otherwise one would be led to make some odd inferences. First, one would have to admit that every noun signifies an accident. Even a noun such as 'human being' would signify only an

Picture in Perspectivist Optics," Isis 72 (1981): 568-589. The division of the soul into a vegetative, a sensitive, and an intellective part is an Aristotelian topos. On the medieval reception, see the thorough historical introduction in Thomas Aquinas Sentencia libri De anima, ed. R.-A. Gauthier (Rome and Paris: Commissio Leonina and Vrin, 1984), pp. 201*-282*.

19. Scotus expounds his species-theory in Ordinatio 1.3.3.1 (Commissio Scotistica 3:209-44), and Quaestiones super lib. Arist. De anima 14 and 17 (Wadding 3:54953 and 575-93). On the sensible species, see John Duns Scotus Ordinatio 1.3.3.2 (Commissio Scotistica 3:299). On the epistemological background of this theory, see Richard E. Dumont, "The Role of Phantasm in the Psychology of Duns Scotus," Monist 49 (1965): 617-633, and Katherine H. Tachau, Vision and Certitude in the Age of Ockham: Optics, Epistemology, and the Foundations of Semantics, 1250-1345 (Leiden: Brill, 1988), pp. 62-81.

20. See Scotus In Perih. 2 (Wadding 1:540). The synonymous use of these expressions was probably initiated by Roger Bacon; see his De multiplicatione specierum 1.1 in Roger Bacon's Philosophy of Nature, ed. David C. Lindberg (Oxford: Clarendon Press, 1983), p. 2. On Bacon's influence on late thirteenth-century semantics, see Tachau, Vision and Certitude, pp. 11-26.

21. Scotus In Perih. 2 (Wadding 1:541). 
accident, for the intelligible species of a human being is an accident existing in the intellect. But this claim is evidently false, since 'human being' signifies a substance and not an accident. Second, one would have to grant that every affirmative predicative proposition is false, since by saying 'Human being is an animal' one affirms that the significate of the predicate term inheres in the significate of the subject term. But the intelligible species of animal considered as a mental accident can never inhere in the intelligible species of human being considered as a mental accident; it is impossible to "merge" two mental accidents. Thus, one could never affirm 'Human being is an animal', which is obviously absurd. Third, every existential claim would be true, even such a claim as 'The Antichrist exists', for the intelligible species of Antichrist considered as a mental accident exists independently of the extramental Antichrist. ${ }^{22}$ In light of the odd consequences following from the claim that a spoken word signifies the species qua mental accident, Scotus insists that a spoken word signifies the species only if the species is considered under its second aspect, namely in its significative function. ${ }^{23}$

But what is the intelligible species qua sign? How is its significative function to be understood? This function, Scotus claims, consists in directing the intellect to something which is not identical with the sign itself. If the intelligible species is taken as a sign, it necessarily directs the intellect to something other than itself, and the same applies to the spoken word. Thus, speaking about signification we have to distinguish two levels of signs. There is a spoken sign (word) that directs the intellect to a mental sign (intelligible species) that itself directs the intellect to a thing. The spoken sign has two significates: (a) the species as its immediate significate; and, (b) the thing as its mediate significate (also called the ultimatum significatum). ${ }^{24}$ It is important to note that the immediate significate is necessarily a sign; it must direct the intellect to the mediate, ultimate significate.

The distinction of two significates enables Scotus to say that by uttering a word we speak about the thing itself and not merely about our intelligible species of the thing, although it is the intelligible

22. Scotus adduces these examples among others in In Perih. 2 (Wadding 1:541).

23. See Scotus In Perih. 2 (Wadding 1:541).

24. Scotus In Perih. 2 (Wadding 1:541). See also In Perih. II 1 (Wadding p 1:583). 
species that is immediately signified. The fact that we signify the thing mediately does not hinder us from signifying it simpliciter. ${ }^{25}$

One might object that this is an oversimplified account, for we do not always signify a thing. When a person speaks about his or her cognitive image of human beings, the noun 'human being' signifies his or her intelligible species of human beings and not the human beings as extramental things. Of course, Scotus replies, it is possible to signify a species not only as a sign for a thing, but also as a significate in itself. But such a signification requires a reflexive act, for the first act of understanding and signifying is always directed toward the thing. For instance, in a first, direct act the noun 'human being' signifies human beings, and in a second, reflexive act it signifies the intelligible species of human beings. Scotus stresses, however, that the significative function is always conventionally imposed on a word. So, the users of the word 'human being' could determine that henceforth this word signifies immediately the intelligible species of human beings and no longer extramental human beings. In that case, there would be a primary signification of a species. ${ }^{26}$ But this fact does not weaken or refute the general thesis that a spoken word, taken in its ordinary imposition, signifies a species only by means of a reflexive act, because the direct signification of a species can be obtained only on the basis of a new conventional imposition that cancels the ordinary one. And since such an imposition is purely conventional, there is no reason why 'human being' should receive a new imposition and signify the species of a human being; any word would do as well.

However, there seems to be a conflict between Scotus's position developed in the two commentaries on De interpretatione (probably written between 1293 and 1297), and his theory presented in the Ordinatio and Lectura (written between 1297 and 1304).27 In his Ordinatio and Lectura, Scotus does not use the distinction between an immediate and a mediate, ultimate significate, but simply says that

25. Scotus In Perih. II (Wadding 1:542).

26. Scotus In Perih. 2 (Wadding 1:543) and In Perih. II 1 (Wadding 1:582).

27. On the chronology of Scotus's work, see C. Balić, "The Life and Works of John Duns Scotus," in John Duns Scotus 1265-1965, ed. John K. Ryan and Bernardino M. Bonansea (Washington, D.C.: Catholic University of America Press, 1965), pp. 1-27. See also the brief remarks in Allan B. Wolter, The Philosophical Theology of John Duns Scotus, ed. Marilyn McCord Adams (Ithaca: Cornell University Press, 1991), p. 103. 
a spoken word signifies a thing. ${ }^{28}$ Some scholars have tried to explain this discrepancy by distinguishing an "early theory," according to which the intelligible species is the primary significate and the thing the secondary, mediate significate, from a "later theory," according to which the thing is the primary significate. ${ }^{29}$

But is there enough textual support for an explanation of this sort, based on the hypothesis of a change in Scotus's thought? Although Scotus does not use the expressions 'mediate' and 'immediate significate' in the putatively later works, he clearly distinguishes between the significate strictly speaking (proprie) and the significate by priority (propter prioritatem). He explains this distinction by comparing the relationship between thing, intelligible species, and spoken word with the relationship between a cause and its effects: 30

Let us posit a cause $x$ that has two effects, $a$ and $b$. The effects are hierarchically structured; $a$ is a proximate effect and $b$ a remote effect. Now one might say that $a$ is the cause of $b$, since $a$ is between $x$ and $b$. But that would be a fallacy, for $a$ has only a priority in the hierarchical order of the effects. The proper cause of $b$ is always the cause $x$. Scotus cites the sun that illumines many parts of a medium as an example, ${ }^{31}$ but he does not spell out the hierarchical relationship among the effects. We may fill out his argument with the following example: the sun illumines a table in illumining all the particles of air, i.e., of the medium between the sun and the table. ${ }^{32}$ The table can only be illumined if the mediating air is illumined. But that does

\section{See note 1 above.}

29. See E. P. Bos, "The Theory of the Proposition According to John Duns Scotus' Two Commentaries on Aristotle's Perihermeneias," in Logos and Pragma: Essays on the Philosophy of Language in Honour of Professor Gabriel Nuchelmans, ed. L. M. de Rijk and H. A. G. Braakhuis (Nijmegen: Ingenium Publishers, 1987), p. 127. Marmo, "Ontology and Semantics," p. 164, speaks more cautiously of a "mature position" in the Ordinatio and Lectura, without sharply distinguishing it from an early theory.

30. See Scotus Ordinatio 1.27.1-3 (Commissio Scotistica 6:97).

31. Scotus Ordinatio 1.27.1-3 (Commissio Scotistica 6:97).

32. It is likely that Scotus has the air in mind when he speaks about the medium of the sun. In Reportatio 2.13.unica (Wadding 23:42-47), he discusses at length the function of light and of the air as transmitting medium. For an extensive discussion (with a new edition of this passage), see Edward R. McCarthy, "Medieval Light Theory and Optics and Duns Scotus' Treatment of Light in D. 13 of Book II of his Commentary on the Sentences," doctoral dissertation, City University of New York, 1976. 
not amount to saying that the air illumines the table. The sun is the proper cause for both the illumination of the medium air (the proximate effect) and of the table (the remote effect). ${ }^{33}$

Identifying the thing with the cause and the signs with the effects, Scotus claims that the intelligible species is the proximate effect $a$, and the spoken word the remote effect $b$. Since the intelligible species is between the thing and the spoken word, it may seem to be the cause of the spoken word. But the intelligible species has only a hierarchical priority; there cannot be a spoken word without there previously being an intelligible species (just as the table cannot be illumined if the medium air is not illumined). Despite this priority, the proper cause of the spoken word is always the thing itself (just as the sun is always the proper cause of the illumination of the table). 34

This relationship between a cause and its two effects, one of which is proximate and the other remote, is a specific type of an essential order, as Scotus explains in the first chapter of De primo principio. ${ }^{35}$ There he distinguishes two types of essential order obtaining between a cause and two effects. (i) Either the first cause $x$ causes the effect $a$, and $a$ in turn causes the effect $b$. In that case there is a causal essential order, for the first effect is the direct cause of the second. (ii) Or the first cause $x$ causes the effect $a$ immediately and the effect $b$ mediately. In that case there is a non-causal essential order; the first effect only has a mediating and not a causal function. Nevertheless, this second type is an essential order, Scotus says, "Since each effect is essentially

33. A. Vos in "On the Philosophy of the Young Duns Scotus: Some Semantical and Logical Aspects," in Medieval Semantics and Metaphysics, ed. E. P. Bos (Nijmegen: Ingenium, 1985), p. 200, tries to explain Scotus's argument by saying: "The sun illumines the whole medium, but the illumination of the nearest parts comes first." This interpretation is correct as regards Lectura 1.27.1-3 (Commissio Scotistica 17:357) where Scotus holds, "pars remota immediate illuminatur a sole sicut pars propinqua, et tamen prius natura illuminatur pars propinqua quam remota (ponendo quod una pars adhuc non illuminet aliam)." But Vos's explanation is hardly adequate for the passage in the Ordinatio (cited in note 31), because there Scotus does not simply say that the sun reaches one part earlier than the other. His point is rather that the sun reaches the remote effect only insofar as it is mediated by the proximate effect.

34. Scotus Ordinatio 1.27.1-3 (Commissio Scotistica 6:97).

35. See Scotus De primo principio 1.9-14 in A Treatise on God as First Principle, ed. Allan B. Wolter (Chicago: Franciscan Herald Press, 1966), pp. 4-8, or Scotus De primo principio 1.4-6 in Abhandlung über das erste Prinzip, ed. Wolfgang Kluxen, 2d ed. (Darmstadt: Wissenschaftliche Buchgesellschaft, 1987), pp. 4-8. 
ordered to some common third which is their mutual cause, it follows that these effects are also essentially ordered to one another." 36 So, we may conclude that Scotus applies a metaphysical distinction on a semantic problem by explaining the relationship between a thing (cause), an intelligible species (proximate effect), and a word (remote effect) as the non-causal essential order obtaining between a cause and two hierarchically structured effects.

This explanation makes it clear that Scotus does not completely give up the distinction between an immediate and a mediate, ultimate significate in his so-called later works. It would hardly be adequate to draw a sharp distinction between an "early" and a "late" theory. Nevertheless, there is a certain development in Scotus's works. In his commentaries on De interpretatione, he speaks about two ways of explaining signification. According to the first, the spoken word signifies the intelligible species; according to the second, it signifies the thing. He favors the second, but seems to be undecided and does not completely reject the first. ${ }^{37}$ In his Ordinatio and Lectura, instead, he makes it clear that he opts for the second way. But his choice includes a subtle addition, a kind of concession to the first way. The spoken word, he says, is only the remote effect of the thing. Between the thing and the spoken word there is still the intelligible species, the proximate effect of the thing. Because of its hierarchical priority (propter prioritatem), the species may be called the immediate significate of the spoken word. Yet it is not the significate strictly speaking (proprie).

One might object that it is misleading to claim that the ultimate significate of a spoken word (according to the commentaries on De interpretatione) or the proper cause of a spoken word (according to the Ordinatio and the Lectura) is a thing, if by 'thing' one understands an extramentally existing thing, since we can speak about objects that do not exist any more (e.g., by uttering the proposition 'Caesar is a man') or which do not yet exist (e.g., by uttering 'The Antichrist will come') or which never exist (e.g., by uttering 'Chimera is an animal'). Scotus replies to this objection that "the thing is primarily signified, however, not insofar as it exists (since it is not in this way that it is

36. Scotus De primo principio 1.14 in Treatise on God (Wolter p. 8); see also Wolter's commentary, pp. 170-171.

37. Scotus In Perih. 2 (Wadding 1:544) and In Perih. II 1 (Wadding 1:585). 
understood per se), but insofar as it is perceived per se by the intellect; that is, [insofar as it is] the essence of the thing which is signified by the definition [and] which is the first object of the intellect." 38 This distinction between the thing insofar as it exists (res ut existit) and the thing insofar as it is understood (res ut intelligitur) plays a crucial role in Scotus's theory of signification and is extensively discussed in both commentaries on De interpretatione. 39

Before considering the details of this distinction, we should counter the objection that the entire argument is self-contradictory. On the one hand, Scotus claims that the thing and not the intelligible species is signified by a spoken word; on the other hand, he says that the "thing as it is understood" is the significate. Is the "thing as it is understood" not the intelligible species, since this species is by definition a cognitive image of the thing, thus representing the thing exactly as it is understood?

This objection overlooks an important point in Scotus's argument. To signify the "thing as it is understood" is not to signify a mental entity representing the thing. Scotus holds that signifying presupposes understanding; a spoken word can be imposed to signify something only if the thing has previously been understood. But this is not tantamount to saying that what the spoken word signifies is the understanding of the thing (i.e., the mental entity representing the thing). Once the spoken word has received its significative function, it always has the capability to signify the thing, even if no one performs an act of understanding. ${ }^{40}$ Thus, 'human being' has the capability to signify human beings even if no one actually thinks about human beings and, consequently, even if no one produces an intelligible species of human beings. It is clear, therefore, that since the "thing as it is understood" is independent of the production of an intelligible species, it ought not to be identified with this species.

The "thing as it is understood," then, is identical neither with the thing as it exists nor with a mental species of the thing. What is it?

38. Scotus In Perih. 2 (Wadding 1:543).

39. The most important passages are Scotus In Perih. 3 (Wadding 1:545-46), the "conclusio" and "solutio," and In Perih II 1 (Wadding 1:586). There is no discussion in the Ordinatio and Lectura. Scotus does not seem to have developed or changed his theory as regards this point.

40. Scotus In Perih. 3 (Wadding 1:545-46). 
Unfortunately, Scotus does not give a detailed answer to this obvious question. In his first commentary on De interpretatione, he simply calls it the "essence of the thing, which is signified by the definition," and in his second commentary, he labels it the quod quid est, thus referring to Aristotle's to ti ên einai. 41 This scant explanation still leaves open the question of what the essence of the thing is. Is it something in the existing thing or distinct from it?

\section{THE ONTOLOGY OF SIGNIFICATES}

In order to find an answer to this ontological question, we shall turn from the commentaries on De interpretatione to the commentaries on the Sentences and on the Metaphysics, which treat ontological problems extensively. In his Reportata Parisiensia Scotus discusses at length the question of how essence and existence are related to each other-a much contested issue at the University of Paris in the late thirteenth century. ${ }^{42}$ Referring to the principle that one should not posit a plurality of entities without necessity, he holds that the essence of a thing is not in reality a distinct entity, preceding the existing thing. ${ }^{43}$ Two entities are distinct in reality only if they are separable, that is, only if one of them can be without the other. The essence of a thing, however, is not a thing separable from the existing thing itself. 44 Nevertheless, there is a distinction between essence and existence, since one can understand the two in distinct ways. Scotus cites the following classical example in order to illustrate this distinction. ${ }^{45}$ Let us admit that no rose exists, and let us further admit per impossibile that the divine intellect does not exist, so that

41. See Scotus In Perih. 2 (Wadding 1:543), cited in note 38, and In Perih II 1 (Wadding 1:583).

42. On the background of this debate, see John F. Wippel, "Essence and Existence," in CHLMP, pp. 385-410.

43. See Scotus Reportatio 2.1.2 (Wadding 22:526).

44. The strong realist designation of the essence as a thing (res), opposed to the existence as one thing to another, was used by Giles of Rome. See John F. Wippel, The Metaphysical Thought of Godfrey of Fontaines: A Study in Late ThirteenthCentury Philosophy (Washington, D.C.: Catholic University of America Press, 1981), pp. 46-53.

45. See Scotus Reportatio 2.1.2 (Wadding 22:527). 
there is not even a rose in the divine intellect. If then a created intellect exists, it can still have an understanding of a rose, since it can grasp the essence of a rose. Thus, the essence of a rose can be understood distinct from its existence, though in reality it is not separable from the existing rose.

Now one could suppose that the distinction between essence and existence is purely conceptual; it is a distinction which the intellect produces by conceiving a thing in different ways. But Scotus rejects the conceptual distinction as well as the real distinction. He claims that, in being grasped by the intellect, the essence is not produced by the intellect. It is rather "in potency before the act of existing." 46 Since the essence is (though only potentially) before the existence, and since being-in-potency does not depend on being grasped or being conceived, the distinction between essence and existence is preconceptual.

So, how is this distinction to be explained? Some modern commentators 47 have argued that here Scotus applies his famous "formal distinction." This intermediary distinction between the real and the conceptual distinction obtains between two rationes 48 of a thing which differ in their definition and can be conceived one without the other, but in reality constitute one thing. ${ }^{49}$ For example, God's attributes (omnipotence, omniscience, infinitude, etc.) are formally distinct, since they can be distinctly conceived, but in reality constitute one thing. ${ }^{50}$ In the same way, one may argue, essence and existence in creatures are formally distinct, since they are distinctly conceivable, though in reality they constitute one individual thing.

Wolter has challenged this interpretation by referring to a passage in the Quodlibeta, where Scotus holds, "One can say that essence

46. Scotus Reportatio 2.1.2 (Wadding 22:528).

47. See Andrew J. O'Brien, "Duns Scotus' Teaching on the Distinction Between Essence and Existence," New Scholasticism 38 (1964): 65-77, with the references there.

48. Besides 'ratio' Scotus also uses the expressions 'formalitas' and 'intentio'. See Scotus Ordinatio 1.2.2.1-4 (Commissio Scotistica 2:355-58), and Reportatio 2.1.6 (Wadding 12:556).

49. On the formal distinction, see Wolter, Philosophical Theology, pp. 27-41.

50. On Scotus's theory of God's nature, see Wolter, Philosophical Theology, pp. 254 277. Note that for Scotus there is a formal distinction only between God's attributes, not between God's essence and God's existence. 
and its existence in creatures are related to each other as quiddity and mode; therefore they are distinct." 51 According to this statement (the authenticity of which is questionable, however, since it occurs in an additio rather than in the text itself), there is a modal distinction between essence and existence. Existence adds the proper mode of being to every essence (with the exception of God's). To the essence of a present, living person, for instance, it adds the mode of actual existence, while to the essence of an imaginary person it adds the mode of fictive existence. Since this mode is only added, it is extrinsic to the essence and "quasi-accidental." 52 Yet existence is not a real accident, because accidents, in a strict sense, are descriptive; they increase the conceivability of the substance in which they inhere. The more accidents we can describe, the better we can conceive the substance. When we examine a table (substance) that is brown, square, hard, etc. (accidents), we can say that the more accidents we are able to describe, the better we understand how the table is. Existence, however, does not increase the conceivability of the essence to which it is added; by grasping the existence of a table we do not gain a better knowledge of how the table is, we just know that it is.

Scotus's ontological discussion of the relationship between essence and existence has a strong impact on his theory of signification. In emphasizing that a spoken word signifies the "thing as it is understood" and not the "thing as it exists," Scotus makes clear that essence and existence are distinctly signified. And what is signified in a distinct way is also understood in a distinct way, since signifying presupposes understanding. ${ }^{53}$

So, we may conclude, Scotus resolves the problem of how a spoken word directly signifies the thing by introducing a crucial metaphysical distinction, namely that between essence and existence. Claiming that a spoken word signifies a thing does not amount to saying that it signifies the thing as it exists, as one may spontaneously suggest. This claim only implies that a spoken word directly signifies the essence of the thing, the essence that is distinguishable from the thing's existence. It is important to note that it is by means of a

51. See Wolter, Philosophical Theology, p. 281; Scotus Quodl. 1 (Wadding 15:9-10).

52. See Wolter, Philosophical Theology, p. 283.

53. Scotus In Perih. 2 (Wadding 1:540). It is assumed, of course, that what is signified is first understood in the same way. 
metaphysical distinction that Scotus answers the semantical question of what a spoken word signifies. He needs such a metaphysical distinction because he tries to escape from the following dilemma: either he sticks to the traditional Boethian answer, claiming that a spoken word directly signifies the intelligible species. But then he has to admit that a spoken word merely signifies a mental entity so that we can never establish an immediate relationship between language and reality. Or he preserves this immediate relationship and claims that a spoken word signifies the existing thing. But then he can hardly explain how we are able to signify something although the significate does not actually exist (e.g., the dead Caesar) or not really exist (e.g., a chimera). Scotus clearly sees that both ways are unsatisfying and chooses a third one that is based on a metaphysical assumption: we can preserve an immediate relationship between language and reality and the possibility to signify non-existing things if we recognize that a spoken word signifies the essence of a thing, distinct from its existence.

But what is the signified essence? Is it something common, or something individual, or something neither common nor individual? This is obviously a complex metaphysical question that needs to be examined in a separate study. I just want to give some hints.

Scotus has confined himself in this discussion to common nouns such as 'human being' and 'animal'. These nouns signify a common essence or common nature (natura communis). 54 'Human being' signifies the nature of every human being, regardless of its existence or nonexistence. However, this human nature is not something additional to or in reality separable from every individual human being. It is always individuated by the "this-ness" (haecceitas) of this or that human being and is therefore signified insofar as it is individuated. ${ }^{55}$ When we say 'Caesar is a man', we signify the common nature man insofar as it is individuated by Caesar's haecceitas. The fact that Caesar no longer

54. See, for instance, Scotus Ordinatio 2.3 (Commissio Scotistica 7:403). For a thorough discussion of the common nature, see Tamar M. Rudavsky, "The Doctrine of Individuation in Duns Scotus," Franziskanische Studien 62 (1980): 62-79.

55. On Scotus's theory of individuation, see Wolter, Philosophical Theology, pp. 6897 (especially 68-69, n. 1, where the most relevant passages are cited); Kenneth C. Clatterbaugh, "Individuation in the Ontology of Duns Scotus," Franciscan Studies 32 (1972): 65-73; Tamar M. Rudavsky, "The Doctrine of Individuation in Duns Scotus," Franziskanische Studien 59 (1977): 320-377. 
exists does not hinder us from signifying his individuated common nature which is distinguishable from his existence. In uttering the true proposition 'Caesar is a man' we predicate of Caesar only the essence man, not the essence together with the existence. Such a predication is always true, because the essence is predicated per se of a subject. ${ }^{56}$ And there must be a per se predication (also called 'essential predication'57), for according to the ontological order Caesar necessarily belongs to the species man. Thus, Caesar necessarily has the essence man.

But what about essential predications such as 'Human being is an animal' where the terms do not signify an individuated common nature? And what about tautologies such as 'Human being is human being' where no essence is predicated? Are these propositions always true, even when no human being exists? ${ }^{58}$ Yes, Scotus says. The first proposition simply expresses that the genus animal (the superior) is predicated of the species ${ }^{59}$ human being (the inferior). And such a predication is always true, whether genus and species are individuated or not, whether a member of the species human being exists or not, because the genus is always predicable of one of its species. Of course, the genus is only predicable of a species belonging to it; 'Gold is an animal', for example, is false because the species gold does not belong to the genus animal. Thus, true predicability of a genus depends on the ontological classification of genus and species. ${ }^{60}$ As for the second proposition, a tautology is merely a particular case of an essential predication. In 'Human being is human being' one predicates the essence human being of the essence human being, and such a selfpredication of an essence is always true, whether a human being exists

56. Scotus In Perih. 7 (Wadding 1:550). See also In Perih II 2 (Wadding 1:585-87).

57. On essential predication (praedicatio in quid), see Scotus Super Universalia Porphyrii 12 (Wadding 1:158).

58. The question Utrum haec sit vera 'homo est animal' nullo homine existente was one of the most favored subjects of the sophism-literature in the late thirteenth century. Alain de Libera, "Roger Bacon et la référence vide," in Lectionum Varietates: Hommage à Paul Vignaux (1904-1987), ed. Jean Jolivet and de Libera (Paris: Vrin, 1991), pp. 91-93, lists 36 texts devoted to this question.

59. The word 'species' is equivocal in the philosophical medieval terminology. In epistemological contexts it refers to the cognitive image, in ontological contexts to a kind subordinate to a genus. Here 'species' obviously stands for a kind.

60. On the predicability of a genus, see Scotus Super Universalia Porphyrii 12 (Wadding 1:166). 
or not. Even 'A chimera is a chimera' (a tautology about a fictive entity) is always true, for in this proposition one predicates the essence of a chimera of the essence of a chimera, regardless of the impossible existence of a chimera. 61

\section{THE SIGNIFICATION OF ACCIDENTAL TERMS}

Since in his commentaries on De interpretatione Scotus limits the discussion to substantival terms, I have been confining my analysis to these terms. However, his claim that spoken words signify immediately the essence of things also applies to accidental terms, in particular to denominative (or paronymous) accidental terms, as his remarks in the commentary on the Categories make clear. In accordance with Aristotle, ${ }^{62}$ he defines the denominativa as those (mostly adjectival) terms that receive their denominatio from abstract terms. ${ }^{63}$ Thus, 'white'-the standard example in the Middle Ages-has its denomination from 'whiteness'. Derived from the abstract substantive, 'white' differs from 'whiteness' only in grammatical form. But does this mean that the denominative term has the same signification as the term from which it has its denomination? This assumption hardly seems convincing, since 'whiteness' is an abstract accidental term which signifies the quality white in an abstract form, i.e., without being in a subject. ${ }^{64}$ The denominative term 'white,' on the other hand, is a concrete accidental term which signifies the quality white insofar as it is in a subject. Used in the proposition 'Socrates is white,' for instance, 'white' signifies exactly Socrates' quality of being white and not whiteness in general. This distinction of abstract and concrete accidental terms raises the question: how can the difference between the significates of 'whiteness' and 'white' be explained ontologically?65

61. See Scotus In Perih. 8 (Wadding 1:550-57, especially p. 551).

62. See Categories 1 (1a12-15) and 8 (10a27-29).

63. See Scotus Super Universalia Porphyrii 16 (Wadding 1:207 and 209) and Super Praedicam. 8 (Wadding 1:456).

64. In this context, 'subject' is not used for the subject term, but for the subiectum (in Greek, hypokeimenon), which is the "support" or "bearer" of the accidents.

65. An excellent introduction to this question, which was extensively discussed in the late thirteenth century, is provided by Sten Ebbesen, "Concrete Accidental 
Scotus holds that every accidental term, whether abstract or concrete, signifies an essence that is distinct from the essence of the subject. Admittedly, the two essences are not equally perfect, since there can be a subject without accidents but no accident without a subject. ${ }^{66}$ Nevertheless, there is an essence of the accident as well as an essence of the subject. One can understand and signify the essence of an accident in two different ways, namely in its own nature (sub ratione propria) or insofar as it is in a subject (inquantum informat subjectum). The first is the abstract mode of signifying which applies to abstract accidental terms; 'whiteness' signifies the essence of whiteness in its own nature, regardless of the inherence or non-inherence of this quality in a subject. The second is the concrete mode of signifying which applies to concrete accidental terms; 'white' signifies the essence of whiteness insofar as it inheres in a subject, for example, in Socrates. Therefore, abstract and concrete accidental terms do not differ in their significate-both signify the quality white-but in their mode of signifying. 67

However, 'whiteness' is only a kind of first-level abstract term, for it does not signify the quality white as being completely abstract. Rather, it signifies this quality as being attributable (although not actually attributed) to different kinds of subjects. For instance, it signifies the quality white as it can be in a wall, and as it can be in milk, and as it can be in the face of a human being, etc. Abstracting from these different possible subjects, we can form a second-level abstract term, e.g. 'quiddity of whiteness' ('quiditas albedinis' or 'albedineitas'), that signifes the pure quality white without any inclination toward a specific subject. 68

Summarizing these subtle distinctions, we can list three kinds of quality terms and, correspondingly, three ways of signifying a quality: (a) concrete accidental terms (e.g., 'album') signify the essence of

Terms: Late Thirteenth-Century Debates about Problems Relating to Such Terms as 'album'," in Meaning and Inference in Medieval Philosophy: Studies in Memory of Jan Pinborg, ed. Norman Kretzmann (Dordrecht: Kluwer, 1988), pp. 107-161. On the competing theories, see p. 118; on Scotus's approach, see especially pp. 120-129. See also Marmo, "Ontology and Semantics," pp. 165-168.

66. Scotus Super Praedicam. 8 (Wadding 1:457).

67. Scotus Super Praedicam. 8 (Wadding 1:457). See also Reportatio 4.12 .1 ad 4 (Wadding 24:140).

68. See Scotus Ordinatio 1.5.1.unica (Commissio Scotistica 4:20-21). 
a quality and indicate by their mode of signifying that the quality inheres in a subject; (b) first-level abstract terms (e.g., 'albedo') signify the essence of a quality and indicate by their mode of signifying that the quality tends to inhere in different kinds of subjects without, however, indicating an actual inherence; and, (c) second-level abstract terms (e.g., 'albedineitas') signify the essence of a quality and indicate by their mode of signifying that the quality is taken in its absoluteness.

The appeal to different modes of signifying is obviously due to the so-called "modistic approach" to semantic theory which Scotus shares with other late thirteenth-century authors such as Boethius of Dacia and Radulphus Brito. Scotus's modistic background has already been the subject of some thorough studies and will not be further investigated here. ${ }^{69}$ The important point in this context, however, is Scotus's appeal to the essence of the accidents. Not only in explaining the signification of substantival terms such as 'human being' and 'animal' but also in delineating the signification of accidental terms he clearly distinguishes between essence and existence. All accidental terms, he claims-whether they are concrete, abstract, or purely abstract-signify the essence of accidents, but by means of their mode of signifying concrete accidental terms make one understand that the accident inheres in an existing subject. So Scotus is consistent in claiming that a spoken word-whether it is a substantival or an accidental term-never signifies the existent thing, but only the essence of a thing.

\section{CONCLUSIONS}

After this overview, we can give a more precise answer to the two questions which resulted from Scotus's classification of signs. The first question, namely how the sign-user relates a spoken

69. See Jan Pinborg, "Bezeichnung in der Logik des XIII. Jahrhunderts," in Methoden in Wissenschaften und Kunst des Mittelalters, ed. Albert Zimmermann, Miscellanea Mediaevalia 7 (Berlin: de Gruyter, 1970), pp. 238-281; and Pinborg, "Die Logik der Modistae," Studia Mediewistyczne 16 (1975): 39-97. A concise evaluation of recent interpretations of the theories of modi significandi is provided by Robert Lambertini, "Sicut tabernarius vinum significat per circulum: Directions in Contemporary Interpretations of the Modistae," in On the Medieval Theory of Signs, ed. Eco and Marmo, pp. 107-142. 
word to its significate, and what exactly the significate is, can be answered as follows: the relationship between a spoken word and its significate is established by conventional imposition and not by a mental representation of the significate. Even if no person performs an act of understanding and representing, the spoken word does not lose its signification. ${ }^{70}$ However, in perfectly using a spoken word the utterer and the hearer of the word need an intelligible species that represents a thing. But this species has only a mediating function; it is not the significate itself. The proper, ultimate significate of a spoken word is always the "thing as it is understood," the essence of a thing, whether the thing is a subject or an accident.

The second question ran as follows: what criteria enable the signuser to judge whether a sign not accompanied by its significate is a true sign? Since in a strict sense only a proposition and not an isolated noun can be called a true sign, ${ }^{71}$ this question is tantamount to the following: what criteria enable the utterer of a proposition to judge whether the proposition is true in the absence of the significate?

An exhaustive answer to this question would require an examination of Scotus's theory of supposition; for in medieval logic, the truth-conditions of a proposition were largely involved with the supposition-conditions of its terms. ${ }^{72}$ For the present, I will limit my answer to the truth-conditions that deal with the signification of the terms. These conditions have to be formulated separately for two classes of truth: (a) necessary truth; and (b) contingent truth.

If a proposition is an essential predication such as 'Caesar is a man' and 'Human being is an animal' or a tautology such as 'Human being is human being' it is necessarily always true, regardless of the presence or existence of the significate, since the significate of both subject term and predicate term is the "thing as it is understood" (the essence of Caesar, the essence of human being, etc.) and not the "thing as it exists."

If a proposition is a contingent predication such as "This table is brown' or 'Caesar is white' it is true only if the predicate term

70. See note 40.

71. See Scotus Quaest. subtilissimae super libr. Met. Arist. 6.3 (Wadding 7:337-48). On Scotus's theory of the proposition, see Bos, "Theory of the Proposition."

72. On Scotus's theory of supposition, see Marmo, "Ontology and Semantics," pp. $168-180$. 
(a denominative term) signifies a quality with the concrete mode of signifying; that is, if it signifies the quality insofar as it inheres in an existing subject. Thus, 'Caesar is white' is false, not because of the significate of 'white' (every accidental term signifies the essence of an accident, not its existence), but because of its mode of signifying. It is false to signify the whiteness as inhering in an existing subject, for Caesar is not an existing subject. 73

But in what respect is Scotus's theory of signification innovative, as I claimed at the beginning of this paper? The distinction between a mediate and an immediate significate is not unusual among late thirteenth-century authors, and the claim that a spoken word signifies primarily and in a proper sense the thing, not the intelligible species, can also be found in Roger Bacon. Bacon seems, in fact, to be much more radical than Scotus, for he holds that a spoken word signifies the thing as it exists; consequently, he denies that words such as 'Caesar' or 'chimera' have a signification. 74

The innovative character of Scotus's theory is less apparent in his semantical explanation of the relationship between a spoken word and a thing than in his attempt to give a metaphysical (in modern terminology, an ontological) foundation to this relationship. By establishing the "thing as it is understood"-the essence of a thing (of an accident as well as of a subject) —as the significate of a spoken word, he sets himself apart from theorists such as Boethius and his followers, who, in establishing the intelligible species as the primary significate, give up the direct signification of things. But he also separates himself from logicians such as Roger Bacon, who, in positing the existing thing as significate, can hardly explain the signification of past, future, or fictive things. Admittedly, Scotus is not the only late thirteenthcentury author who rejects the Baconian approach as well as the Boethian; Radulphus Brito also calls the "thing as it is understood" the

73. See Scotus In Perih. 8 (Wadding 1:553-54). See also Bos, "Theory of the Proposition," p. 129.

74. See Roger Bacon Compendium studii theologiae 2.2 (Maloney p. 68). On Bacon's semantics, see Thomas S. Maloney, "Roger Bacon on the Significatum of Words," in Archéologie du signe, ed. Lucie Brind'Amour and Eugene Vance, Papers in Medieval Studies 3 (Toronto: PIMS, 1982), pp. 187-211; and Maloney, "The Semiotics of Roger Bacon," Medieval Studies 45 (1983): 120-154. On his theory of terms which signify non-existing things, see de Libera, "Roger Bacon et la référence vide." 
immediate significate. ${ }^{75}$ But so far as I can see, Scotus gives the most comprehensive answer, based on an elaborate metaphysical doctrine.

So, is Scotus's appeal to the essence of a thing the perfect solution? Only if one is willing to accept the essence-existence distinction, a distinction that is not unproblematic, as Ockham's harsh critique and the attacks of other fourteenth-century philosophers make plain. ${ }^{76}$ In trying to ensure the direct signification of things and the possibility of signifying non-existing things, Scotus invokes a specific kind of entity as significate. Therefore, who accepts his answer to the semantical question of what a spoken word signifies will also have to accept a good deal of his controversial metaphysical doctrine. ${ }^{77}$

\section{University of California, Los Angeles}

75. See Pinborg, "Die Logik der Modistae," p. 46, who quotes the Quaestiones super Isagogen Porphyrii.

76. On Ockham's objections, see Marilyn McCord Adams, William Ockham (Notre Dame, Ind.: University of Notre Dame Press, 1987), pp. 46-52. The critique was mainly directed against Scotus's modal distinction (or formal distinction, according to other interpretations) between essence and existence. Armand Maurer, "William of Ockham on Language and Reality," Sprache und Erkenntnis 2:800, shows clearly that Ockham disagreed with Scotus above all over the ontological commitments of his theory of signification, not over the semantic aspects in a narrow sense.

77. I am grateful to Sten Ebbesen, Gyula Klima, Norman Kretzmann, Robert Pasnau, Fiona Somerset, and Paul Vincent Spade for helpful comments on earlier drafts of this paper. 